\title{
THE LIFE HISTORY OF KELLIA SUBORBICULARIS
}

\author{
By Marie V. Lebour, D.Sc. \\ Naturalist at the Plymouth Laboratory
}

(Text-fig. I)

Kellia suborbicularis (Montagu) has long been known to be viviparous. Lovén (I848) mentions this fact and Jeffreys (I863, p. 227) quotes Mr Clark who "found in the ovary of one individual ova in an advanced state with fully formed testaceous fry". It is probable, however, that these shelled larvae were in reality contained in the gill pouch where later workers have found them. Pelseneer (I935, p. 5I7) says that the eggs are incubated in the internal gill lamella, and this was also observed by myself.

It is striking that although the shelled larva is extremely small when liberated (shell $0.064-0.08 \mathrm{~mm}$. in length), the late planktonic larva is very large (shell $0.30-0.37 \mathrm{~mm}$. in length) and one of the most conspicuous bivalve veligers in the plankton. This indicates a prolonged free-swimming life quite unlike that of the oyster, Ostraea edulis, whose shelled larvae are liberated only to lose the velum in a few days. These late larvae of Kellia have been kept in bowls and plunger jars in the Plymouth Laboratory until they metamorphosed and for months afterwards, growing into beautifully clear and transparent individuals which undoubtedly belonged to this species.

Kellia suborbicularis is placed by Winckworth (I932) in the Erycinidae, but this family is closely related to the Leptonidae, Montacutidae and Galeommatidae, most or all of whose members are viviparous. Lovén (I848) described the young shelled stage of Montacuta ferruginosa and M. bidentata, the latter species now being referred by Winckworth to Mysella. Both keep their young in the gill pouch until the shelled stage and Lovén's beautiful figures show that the early shelled stage in each of them is very like that of Kellia. Both, however, are larger when ejected and more developed (M. ferruginosa $0.14 \mathrm{~mm}$. long, M. bidentata O.I5 mm. long, Kellia suborbicularis 0.064$0.08 \mathrm{~mm}$. long). After being fed on flagellates Kellia at $0 . \mathrm{I} 2 \mathrm{~mm}$. had developed further, although smaller than either of the others. The shape of the newly ejected shell is similar in all three. Kellia grows rounder as it develops. The later stages of the other two are not known; but certain large veligers in the Plymouth plankton, now being investigated, seem to belong to Mysella bidentata, and if this is proved to be the truth we have another species, similar to Kellia, in which there is much growth in the free-swimming stage before metamorphosis. 
When we realize that Lovén's work is now ninety years old it is somewhat astonishing that so little has been added to our knowledge of these most interesting larvae. Lasaea rubra incubates its eggs until a very late stage. Galeomma turtoni gave out embryos during the night of September I3 I937, which were in a much less advanced state than those of Kellia, having no shell although moving freely, the round embryo measuring $0.07 \mathrm{~mm}$. across (these facts were kindly communicated by Miss Popham who is working at the group). A young Turtonia minuta, belonging to the same family as Kellia, grown in a plunger jar but in which the free-swimming stage was not noted, measured only $0.64 \mathrm{~mm}$. in length and was just like the adult.

Kellia suborbicularis is fairly abundant at Plymouth on rocky shores in crevices and in dead shells and is also frequently dredged from deeper water in the Sound and outside, especially from the Stoke Point Grounds in crevices of red rock or in empty burrowing shells. Developing eggs were found in the gill pouches in May, July and August, but no eggs were seen in the winter months although several specimens contained active sperm in October. Shelled larvae were given off in September and October. Late larvae are present in the plankton in any month of the year both inside and outside the Sound, but especially in summer and early autumn. At this time they are some of the most conspicuous bivalve veligers, occurring with others of about the same size (Lima, Saxicava and, possibly, Montacuta). The breeding season appears to be spring, summer and early autumn with occasional larvae in winter.

Odhner (19I4) found Kellia suborbicularis ripe in April at Rovigno, but does not mention the young in the gills. He notes the benthonic young in May with almost circular form, diameter (=length) $0.3 \mathrm{I} \mathrm{mm}$.; having a violet streak below the middle of the umbo and a greenish liver, and later stages with a red-brown pigment fleck under the adductors. It is at about this size that the larvae begin to lose the velum at Plymouth, but the violet streak and red spot were not noticed although there is frequently a red colour just inside the mantle edge.

The smallest developing egg seen from the gill pouch measured $0.025 \mathrm{~mm}$. across and had divided into two segments; but in the same brood there were many celled spherical embryos $0.05 \mathrm{~mm}$. across. On September I4 1937 Miss Popham found newly extruded larvae which had hatched out in a bowl during the night. Another brood was given out on October II-I2 during the night. Those from the September brood were very numerous and were swimming actively. The oval shell (Fig. I $a, b$ ) was perfectly transparent, smooth and colourless, the hinge line nearly straight, the length $0.064 \mathrm{~mm}$. The organs were only feebly differentiated; but the velum, which was nearly half the length of the shell, was a fairly strong swimming organ surrounded by long and powerful cilia. A long and stronger cilium (the flagellum) was situated in the centre of the velum. The velar muscles were strongly developed.

The larvae given out in October were slightly larger and more developed 


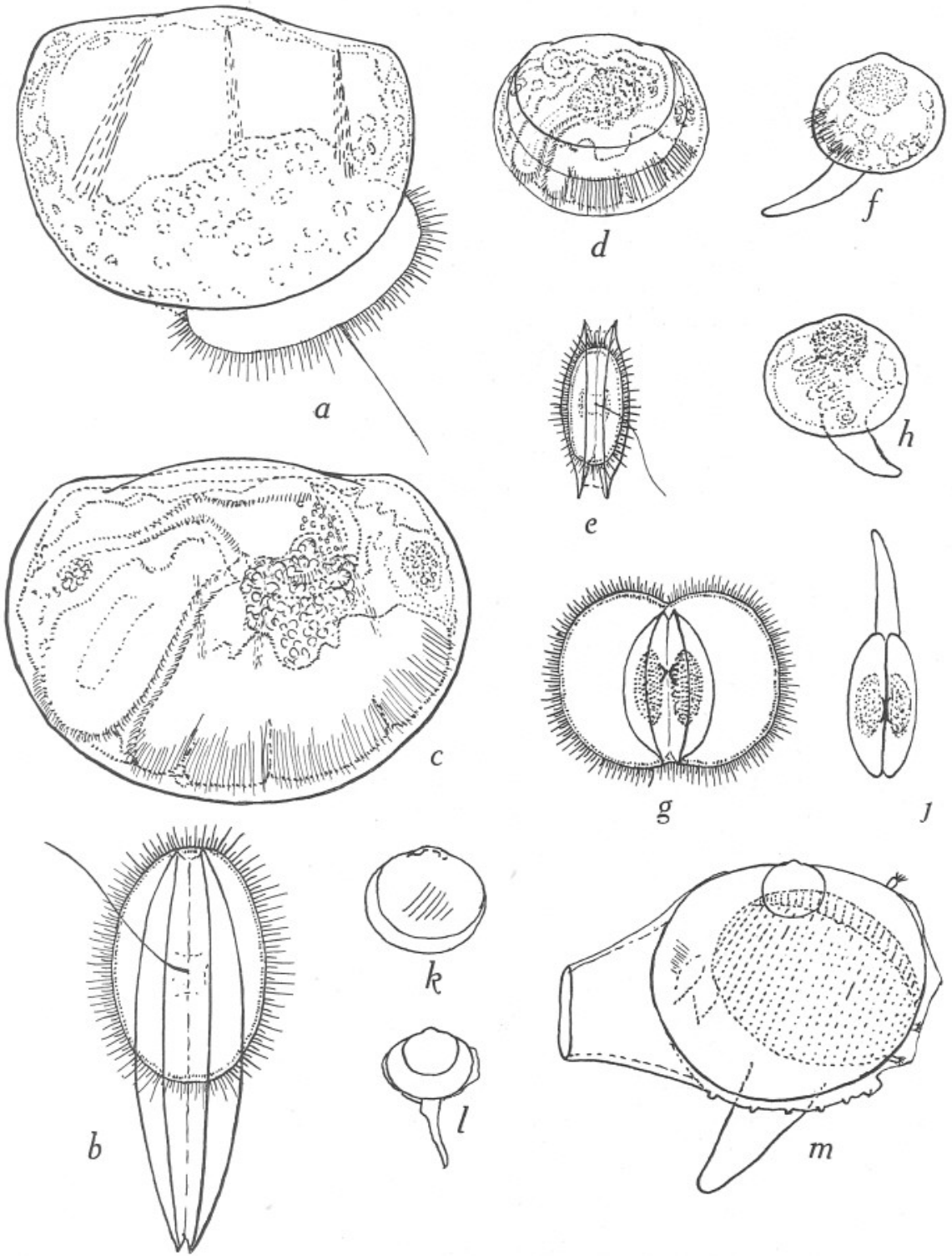

Fig. I. a, veliger of Kellia suborbicularis newly extruded from parent's pouch, $0.064 \mathrm{~mm}$. long, lateral view, September; $b$, the same, ventral view, swimming; $c$, veliger one day after extrusion, $0.08 \mathrm{~mm}$. long, lateral view, October; $d$, veliger reared in plunger jar, extruded by parent in October, I4 days old, lateral view, O.I6 mm. long; $e$, the same, ventral view, swimming; $f$, late veliger from plankton, lateral view, $0.36 \mathrm{~mm}$. long; $g$, the same, swimming, ventral view; $h$, newly metamorphosed larva, lateral view, $0.37 \mathrm{~mm}$. long; $j$, the same, dorsal view; $k$, young shell, reared from planktonic veliger, $0.32 \mathrm{~mm}$. long; $l$, slightly older shell, reared from planktonic veliger, $0.48 \mathrm{~mm}$. long; $m$, older shell reared from planktonic veliger, I. $2 \mathrm{~mm}$. long 
than the September brood. These were placed in a plunger jar and given very small flagellates as food. On the morning of October I3, being one day old, they were swimming freely and feeding. The larva (Fig. I c) measured $0.08 \mathrm{~mm}$. in shell length. The stomach, mouth and intestine were developed and were strongly ciliated, the stomach being full of flagellates. The liver was beginning to appear as a roundish mass at the side of and below the stomach. The anterior adductor muscle was fairly well developed, the posterior just beginning to appear below the end of the intestine. The velar muscles could still be seen, although hidden to a certain extent by the developing organs, and the velum was considerably larger. These larvae grew slowly but were active and fed well, the food being renewed every few days. When I4 days old they measured $0.1 \mathrm{~mm}$. in shell length and $0.08 \mathrm{~mm}$. in depth. The liver and stomach were turning a pale yellow, the stomach still being full of the flagellate food; the intestine was becoming twisted and the posterior adductor muscle was larger. The velum had increased in size and was held more centrally than in the very early larva, the flagellum being still conspicuous. At 3 weeks old the largest larva (Fig. I $d, e$ ) measured $0.16 \mathrm{~mm}$. in shell length, but some were much smaller. At this point they ceased to grow, although still active and feeding, and they lived for a further 6 weeks. The larva at this size is very like the smallest recognized in the plankton; it has gradually grown from an oval to a round shape, the velum growing larger until it projects well beyond the shell.

It is probable that growth in the plunger jar is much slower than it is in nature, although the larva probably stays for a considerable time in the plankton in order to attain such a large size before metamorphosis. Veligers about $0.20 \mathrm{~mm}$. in shell length may be recognized in the plankton and these are very similar to the largest reared in the plunger jar. They are, however, at this stage not very easy to differentiate from other species. The late larvae are easily recognizable. The largest veliger (Fig. I $f, g$ ) was $0.37 \mathrm{~mm}$. in shell length, slightly less in breadth, and nearly spherical. From a shell length of $0.30-0.37 \mathrm{~mm}$. the larva is ready to metamorphose. It has a faint yellowish tinge with touches of red irregularly present and is sometimes red all round the inside of the mantle margin. The general effect is colourless. The digestive gland is very conspicuous, forming two large greenish grey masses on each side just below the umbo. There are two to four gill slits, well-formed adductor muscles and a long contractile foot. The velum is very large and is slightly divided centrally at the anterior and posterior ends, the beginning of a bilobed structure usual in gastropods but very rare in bivalves. The velum is surrounded by powerful cilia and has lost the central flagellum; the whole organ projects far beyond the shell on each side. At this stage the animal can either crawl or swim and is now ready to metamorphose. The umbos of the shell are peculiarly prominent. The velum is now lost and the animal descends to the bottom.

These late veligers rapidly metamorphosed in plunger jars (Fig. I $h, j$ ) and 
the shell put on growth all round (Fig. I $k, l$ ); the gills increased quickly and the mantle began to close up, showing the typical anterior and posterior siphons, the foot projecting from a central opening. At a length of $\mathrm{r} \cdot 2 \mathrm{~mm}$. the shell and animal are those of a typical Kellia, the embryonic shell still showing conspicuously at the apex (Fig. I $m$ ). One specimen, kept for 6 months, measured $3.25 \mathrm{~mm}$. in length and except for the absence of reproductive organs was in every way like the adult. Here again growth is probably slow, compared with that in natural surroundings, and it seems likely that the shell grows to its full size in a year. One female collected in August contained developing embryos and measured only $4 \mathrm{~mm}$. in length, the largest being about $9 \mathrm{~mm}$.

Newly metamorphosed Kellia were frequently found crawling on and in the red rock dredged from the Stoke Point Grounds. The smallest had a length of $0.32 \mathrm{~mm}$. and intermediate stages between these and adults also occurred frequently; all were exactly similar to those reared in the plunger jars.

It seems certain that the young enter the holes and empty shells at a very early stage - a fact already noted by Montagu (I863, p. 39) who first described the species and stated that "it is to be found in holes in limestone the entrance being much smaller than the shell so that it must have entered in a young state".

It is thus established that Kellia suborbicularis, although it incubates its eggs until the larvae have formed a shell, must none the less remain in the plankton for a long time. It possesses a late veliger which is one of the largest planktonic bivalve larvae seen, and as the larvae are large and very numerous and occur practically throughout the year they must be important economically. The adult Kellia is known to form part of the food of the haddock (Jeffreys, I863, p. 227).

\section{REFERENCES}

Jefrreys, J. G., I863. British Conchology, Vol. II, pp. I-464.

LovÉn, S., I848. Beiträge zur Kenntniss der Entwicklung der Mollusca Acephala Lamellibranchiata. Abhandl.'K. Schwed. Ak. Wiss., I848. (Republished in 1879 at Stockholm with additional notes, pp. I-39.)

Montagu, G., I863. Testacea Britannica, pp. I-606.

ODHneR, N. H., I9I4. Notizen über die Fauna der Adria bei Rovigno. Beiträge zur Kenntniss der marinen Molluskenfauna von Rovigno in Istrien. Zool. Anz., Bd. XLIV, 4, pp. I56-70.

Pelseneer, P., I935. Essai d'ethologie zoologique des Mollusques. Acad. Roy. Belgique Cl. Sci. Publications de la Fondation Agathen de Potter, No. I, pp. I-662.

Winckworth, R., I932. The British Marine Mollusca. Fourn. Conch., Vol. I9, No. 7, pp. $21 \mathrm{I}-52$. 